DOI: $10.46400 /$ uygur.865482

\title{
UYGUR DİASPORASININ YAPISAL ÖZELLİKLERİ
}

\author{
[Araştırma Makalesi / Research Article]
}

\author{
Mehmet Emin BEGTIMUR*
}

Geliş Tarihi: 20.01.2021

Kabul Tarihi: 05.05.2021

$\ddot{O} z$

Varoluşundan bu yana insanoğlu barınma ve gıda ihtiyaçlarını karşılamak amacıyla doğal kaynaklar bulmak, tarım alanlarına sahip olmak gibi ekonomik nedenlerden bulunduğu yerleri terk ettiği gibi; sel, kuraklık, deprem ve çölleșme gibi doğal afetlerin yanısıra; savaş, işgal, zorlu sürgün gibi siyasi sebeplerden dolayı hem göç etmek zorunda kalmıştır. Doğup büyüdüğü toprakları hem içsel hem dışsal faktörlerden dolayı isteyerek ya da istemeyerek terk etmiștir. Tekerleğin icat edilmesinden sonra insanların doğdukları ya da bulundukları coğrafyalardan başka yerlere hareket etmesi daha kolaylaşmıştır. Buhar makinesine bağlı olarak gelişen motorlu taşıtlarla seyahat ve göç hareketleri daha da hızlanmıştır. Yüksek teknolojiyle donatılmış günümüz dünyasında ise hiç azımsanmayacak kadar insan kolayca mekân değiștirebilmekte ve türlü nedenlerle anayurtlarından uzak coğrafyalarda yaşamaktadır. Bir yandan yerleștikleri coğrafyaların kültürel, ekonomik ve coğrafik koşullarına uyum sağlamaya çalışırken bir yandan da kendi kökenleriyle olan bağı korumak için aynı geçmişe sahip insanlarla bir arada yaşamaya çabalamaktadır.

Bu çalışmada, diasporanın tanımı, yapısal özellikleri ve farklı perspektiflerden sınıflandırılmasından yola çıkılarak, 2017 yılından beri belirmeye başlayan Uygur diasporası genel hatlarıla incelenmektedir. Bu bağlamda, Uygur diasporasının örgütleneme nedenleri, anavatanının siyasi durumu, şekillenmeye başladığı tarihsel dönem ve yapılanma tarzları irdelenerek Uygur diasporasinın mevcut durumu açıklanmaya çalışılmıştır.

Anahtar Kelimeler: Diaspora, Uygur, Yapısal Özellikler, Göç, Anavatan.

\section{STRUCTURAL CHARACTERISTICS OF UYGHUR DIASPORA}

\begin{abstract}
Since its existence, human beings left their places for economic reasons such as finding natural resources and owning agricultural lands to meet their shelter and food needs; besides natural disasters such as flood, drought, earthquake and desertification; also had to emigrate due to political reasons such as war, occupation and forced exile. People left the land they were born and raised in, willingly or unwillingly, due to both internal and external factors. After the invention of the wheel, it became easier for people to move from the geographies where they were born or live to another. Travel and migration movements have accelerated with motor vehicles that have developed depending on the steam engine. In today's world equipped with high technology, no less than a small number of people can easily change places and live in geographies far from their homeland for various reasons. On the one hand, while trying to adapt to the cultural, economic and geographic conditions of the places they have settled in, on the other hand, they strive to live together with people from the same background in order to preserve their connection with their origins.

In this study, based on the definition of diaspora, its structural features and classification from different perspectives, the Uyghur diaspora, which has started to appear since 2017, is reviewed in general terms. In this context, it was tried to explain the current status of Uyghur diaspora by rewieving the reasons for the
\end{abstract}

${ }^{*}$ Dr. Öğr. Üyesi, İstanbul Gelişim Üniversitesi, Uygulamalı Bilimler Yüksekokulu, Yeni Medya ve İletişim Bölümü, eposta: mbegtimur@gmail.com.

Orcid: 0000-0003-4458-3976. 
organization of the Uyghur diaspora, the political situation of its homeland, the historical period in which it started to take shape and its structuring styles.

Keywords: Diaspora, Uyghur, Structural Characteristics, Migration, Homeland.

\section{Giriş}

İnsanlık tarihinde ilk sürgün, ilk insan olan Âdem ata ve eşi Havva ananın yasaklı meyveyi yemesinden sonra cennetten dünyaya gönderilmesiyle başlamıştır. Bu sürgünden itibaren Âdem ata ve onun neslinden çoğalan insanoğlu şimdiye kadar ilk insanın yaratıldığı anayurduna (cennete) olan özlemini, dönüş arzusunu ve orada sonsuz mutluluğa kavuşacakları düşüncesini taşımaktadır. Gerek İslamiyet'te gerek Hristiyanlık'ta gerekse de diğer dinlerde olsun "insanoğlunun asıl yurdunun cennet olduğu ve nihayetinde anayurtlarına dönecekleri" düşüncesi, inananlara hâkim bir düşünce olmuştur. Bu açıdan bakıldığında, cennete özlem duyan ve bir gün oraya döneceklerine inanan insanlar, bu dünyada bir sürgün hayatı yaşıyor demektir.

Eskiden beri insanoğlu barınma ve gıda ihtiyaçlarını karşılamak, doğal kaynaklar bulmak, tarım alanlarına sahip olmak gibi ekonomik nedenlerden bulunduğu yerleri terk ettikleri gibi sel, kuraklık, deprem, kuraklık ve çölleşme gibi doğal afetlerin yanı sıra savaş, işgal, zorlu sürgün gibi siyasi sebeplerden dolayı göç etmek zorunda kalmıştır. Gerek zorla gerekse kendi isteğiyle anayurdundan göç eden insanlar, göç ettikleri coğrafyanın yaşam koşullarına uyum sağlayarak o toprakları anayurt kabul ettikleri gibi, anayurtlarından ayrılmalarından yüzyıllar geçmesine rağmen anayurt özlemini taşıyan ve koşullar uygun hale geldiğinde anavatanlarına dönme hayallerinden vazgeçmeyen topluluklar hem mevcuttur. Çeşitli sebeplerle anavatanlarından uzaklaşan ve anavatan özlemi taşıyan topluluklar ele alındığında "diaspora" kavramı karşımıza çıkmaktadır.

\section{Diaspora Kavramı}

Yunancadaki "için, dolayı" anlamına gelen "Dia” sözcüğüyle "tohum, çekirdek" anlamına gelen "Sporos" sözcüklerinin birleşmesinden şekillenen diaspora kelimesi "her tarafa dağılmış, yayılmış ve saçılmış tohumlar" anlamını taşımaktadır (Yaldız, 2013: 290). Bu kelimenin kullanımına MÖ 5. yüzyılda, Sofokles, Heredot ve Tukidides'te rastlanmıştır. Diaspora teriminin günümüzdeki kullanımı açısından, İbranice Kitab-ı Mukaddes'in İskenderiyeli 70 Yahudi asıllı bilgin tarafından yapılan Yunanca çevirisindeki kullanımı dikkat çekmektedir. "Yetmişler İncili" (MÖ 3. yüzyll) olarak anılan bu dini kitabede diaspora sözcüğü toplam 12 kez dile getirilmiştir (Baumann, 2000: 313).

Diaspora kelimesinin kökeni ve anlamına ilişkin farklı araştırmacıların farklı görüş ve tartışmalarına rağmen bu kelimenin genel olarak "dağılma ve saçılma" anlamına geldiği üzerinde bir uzlaşma olduğunu ifade etmek mümkündür. Bu kelimemin bilinen ilk kullanımına, Yahudilerin İÖ. 598 veya 587 yıllarında Filistin'den Babil'e sürgün hikayesini kaleme alan eserlerde rastlanılmaktadır (Dufoix, 2011: 1). Bu kullanımından günümüze kadar diaspora kelimesi, anayurt olarak bildikleri coğrafyadan her türlü sebeplerden ötürü ayrılmak ve sürgün edilmek zorunda kalan toplulukları ifade etmek için kullanılmıştır.

Kavram olarak yeni vatanda ulusal ya da milli kimlik korunurken, orijin yurduna dönme hayalidir (Alfred, 2015: 88). "Diaspora, kendi yurdundan ya da devletinden ayrılmış ve başka uluslar arasına dağılmıș, ancak kendi ulusal kültürünü koruyan bir ulus ya da ulusun bir parçası için kullanılan Yunanca bir terimdir." (Dufoix, 2011: 27). William Safran'ın yaklaşımıyla diaspora, kendi anayurtlarına ilişkin kolektif bir hafıza, vizyon ve geçmişe sahip bireylerdir; fiziksel konumu, geçmişi ve başarıları ile birlikte atalarının orijin 
yurtlarını ideal evleri olarak gören ve şartlar uygun olduğu takdirde kendilerinin ve nesillerinin orijin yurtlarına geri döneceği hayalini taşıyan insanlar grubudur (Laycock, 2012: 105).

Sonuç olarak, diaspora hem belirli bir noktadan başlayan dağılmayı ifade etmek için kullanılan bir terim; hem etnik, ulusal ya da dini bir topluluğun bir ya da birden fazla ülkede cemaatleşmiş ve örgütlenmiş halidir; hem de birden fazla yurda dağılmış nüfusu, bu nüfusların dağıldıkları coğrafyaları, belirli bir coğrafya ile sınırlı olmayan her türlü ilişki ve iletişim uzamını ifade etmektedir (Dufoix, 2011: 13). Diğer bir ifadeyle diaspora, menşe coğrafyalarından "zorunlu" ya da "gönüllü" olarak ayrılarak, başka coğrafyalarda başka ulusların arasında yaşayan, menșe coğrafyaları ile maddi ve manevi her türlü ilişkilerini devam ettirmeye ve korumaya çalışan milli, dini ya da etnik azınlık gruplardır.

\section{Diasporanın Temel Özellikleri}

Diaspora kavramına ilişkin birçok araştırmacı farklı ölçüt ve model oluşturma girişimlerinde bulunmuştur. Bu araştırmacılardan biri olan William Safran, diaspora terimini, mensupları aşağıdaki altı özelliğin çoğunu taşıyan vatansız etnik, dini ve milli azınlık toplulukları için kullanılmasının uygun olacağını öne sürmektedir (Safran, 1991: 83):

1) Kendilerinin ya da atalarının aynı "merkez"den ayrılarak iki ya da daha fazla coğrafyaya yayılmış olması,

2) Anayurtlarına ilişkin ortak bir toplumsal hafıza, ortak bilinç, ortak anı ve ortak geçmişe sahip olması ve bu toplumsal hafiza ve sembolik varlıkların korunması,

3) Ev sahibi ulus ya da toplum tarafından tam olarak kabul görmelerinin imkansızlığı veya ev sahibi toplum tarafından dışlandığına ve kabul edilmediklerine inanmaları ve dolayısıyla kendilerini o coğrafyaya ait değillermiş gibi hissetmeleri,

4) İmkân ve koşullar uygun olduğu takdirde, kendilerinin ya da nesillerinin, sembolik olarak varlığını kabul ve idealize ettikleri anayurtlarına geri dönme niyetlerinin korunması,

5) Anayurtlarının korunması, gelişmesi, yeniden kazanılması ve güvenliğinin sağlanmasının tüm üyelerin ortak sorumluluğu olduğu bilincini taşıyor olması,

6) Anayurtlarıyla duygusal ve fiziksel bağlarını bireysel ya da kolektif bir şekilde devam ettiriyor olmasi.

Safran'ın ifade ettiği bu özellikler, 20. yüzyılın ilk yıllarındaki Yahudi diasporasının temel özellikleriyle örtüşmektedir. Ama günümüzde kendilerini diaspora olarak tanımlayan birçok toplululuğun (örneğin Çin diasporası ve Afrika diasporası) ve hatta Yahudi diasporasının birtakım özellikleri ile pek örtüşmemektedir (Yaldız, 2013: 303).

Robin Cohen, Yahudi diasporasının temel özelliklerini ve zamanla sürekli anlam değişikliğine uğrayan diaspora terimini daha geniş bir çerçeveye oturtmaya çalışmıştır. Bu sebeple Cohen, Safran'ın ölçütlerini temel almış fakat bu ölçütler üzerinde bir takım değişikliğe gitmiştir. Yani ana vatanın idealize edilmesini, bu ülkenin varlığını devam ettirmek ve güvenliği için ortak hareket etmekle birleştirmiştir. Bu özelliklere dört ölçüt daha ilave ederek diasporanın ortak özellikleri listesini dokuza tamamlamıștır. Cohen'in oluşturduğu diasporanın özellikleri listesini şu şekilde ifade etmek mümkündür (Cohen, 1997: 180-187):

1) Anayurtlarından beklenmedik kriz ve travmatik (savaş, hastalık, sürgün vb.) olaylar yüzünden zorunlu olarak ayrılması,

2) Anayurtlarından iş, ticaret veya toplu göç gibi amaçlarla ayrılıyor olması, 
3) Ortak bir bellek ve anayurda ilişkin serüvene sahip olmak,

4) Sembolik olarak varlığı kabul edilen bir ana vatanın idealize edilmesi,

5) Anayurtlarına geri dönüş çabalarının olması,

6) Eski dönemlerden beri sürdürülen güçlü bir etnik, milli ya da dini grup bilinci,

7) Ev sahibi devlet ya da ulusla bazı sorunların yaşanması,

8) Diğer ülkelerde yaşayan soydaşlarıyla sürekli dayanışma ve yardımlaşma duygularının olması,

9) Kendilerini anlayış ve hoşgörü ile karşılayan ev sahibi ülkelerde, daha iyi bir yaşam sürdürme ihtimalinin bulunmaması.

Cohen'in ilave ettiği "Anayurtlarından beklenmedik kriz ve travmatik (savaş, hastalık, sürgün vb.) olaylar sebebiyle zorunlu olarak ayrılması" ve "Anayurtlarından iş, ticaret veya gönüllü toplu göç gibi amaçlarla ayrilıyor olması" gibi özellikler günümüz diasporasının tanımlanmasında ve genel çerçevesinin olușturulmasında çok önemli rol oynamaktadır. Zira bundan önceki tanımlamalarda diaspora, tanımlarında daha çok anayurtlarından "zorunlu" göç eden etnik milli ya da dini topluluklar odak noktası olmuşken, Cohen'in bu hususları da diasporanın özellikleri listesine ilave etmesiyle, iş bulmak, ticaret vb. "gönüllü (zorunlu olmayan)" göç hareketleriyle anayurtlarından ayrılan topluluklar da diaspora olarak tanımlanabilmiştir.

Kavramın tanımı ve özelliklerine ilişkin birtakım araştırmalar yapan Gabriel Sheffer "Diaspora Politcs: At Home Abroad" adlı çalışmasında, yurt dışında (anayurtlarından başka bir coğrafyada) yaşayan toplulukların diaspora olarak adlandırılabilmesi için aşağıdaki niteliklere sahip olması gerektiğini ifade etmektedir (2003: 9-10):

1) Anayurtlarından zorunlu ya da gönüllü göç neticesinde ayrılmıştır.

2) Mensupları aynı etnik milli ya da dini kökten geldiklerini kabul etmektedir.

3) Anayurtlarının dışında bir ya da birden fazla ülke ve coğrafyalarda azınlık topluluk olarak yaşamını sürdürmektedir.

4) Mensupları, bir yandan anayurtlarıyla bir yandan da diğer ülkelerde yaşayan soydaşlarıyla olan ilişkilerini sürdürmektedirler.

5) Topluluğun mensupları birbirleriyle sürekli yoğun bir yardımlaşma ve dayanışma içindedirler. Siyasi, iktisadi ve diğer toplumsal konularda çok faaldirler.

6) Aktif olarak rol aldıkları sosyal, kültürel, siyasi ve ekonomik etkinliklerden başka, mensupları ana yurtları, ev sahibi ülkeler ve başka uluslararası aktörler arasında kurulan ilişkileri etkileyerek devlet-ötesi iletişim ağlarını şekillendirir.

Cohen ve Sheffer, Safran'a göre daha geniş bir bakış açısıyla, iş aramak, ticaret vb. gönüllü göç hareketleriyle anayurtlarından ayrılan toplulukların da diasporayı oluşturabileceğini ortaya koymuştur. Bu açıdan bakıldığında, Cohen ve Sheffer'in oluşturduğu diaspora özellikleri, ulaşım ve haberleşme teknolojilerinin son derece gelişmesiyle bir kişinin dünyanın herhangi bir ülkesine kolayca göç edebildiği günümüz dünyasının diasporasını daha açık ve kapsayıcı bir şekilde yansıtmakta ve tarif etmektedir. Dolayısıyla anavatanlarının dışındaki coğrafyalarda yaşayan herhangi bir topluluğu diaspora olarak nitelendirmek için yukarıda belirtilen kriter ve özeliklerin temel alınması, diaspora konusunun daha geniş bir perspektifle incelenmesine ve anlaşılmasına olanak sağlayacaktır. 


\section{Diasporaların Sinıflandırılması}

\subsection{Diasporanın Örgütlenme Nedenleri Açısından Sınıflandırılması}

Anavatanlarından ayrılarak yurt dışında hayatlarını devam ettiren toplulukların örgütlenmelerinin ardında genel olarak din, ticaret, siyaset, aynı ırk ve aynı kültür gibi öğeler yatmaktadır. Yani bunlardan herhangi biri ya da birkaçının kombinasyonu, diasporanın oluşmasına neden olan temel öğelerdir. Michel Bruneau bu öğeleri esas alarak dört tür diaspora tipolojisinden bahsetmektedir (Bruneau, 2010: 77).

1) Ticari diasporalar: Bu tür topluluklar yalnızca bir ticari amaç, maddi yatırım ve girişim çevresinde şekillenir. Birincil amaçları ticaridir, diğer her şey buna bağlı ya da ikinci plandadır. Çin ve Hint diasporaları buna örnek olarak gösterilebilir. Hint diasporası farklı inançtan (Müslümanlar, Hindular, Hristiyanlar vb.) kişilerin ögütlenmesiyle ortaya çıktığından, burada din temel bağlayıcı ve şekillendirici rol oynamaz. Bu tür diaspora mensuplarını birbirleriyle bağlayan tek ve en önemli şey, ticari amaç ve çıkarlarıdır.

2) Dini diasporalar: Bir dinle bağlantılı ve din temelli oluşan topluluklardır. Yahudi, Yunan ve Ermeni diasporaları buna bir örnek teşkil edebilmektedir. Diaspora mensuplarının inandıkları din, kutsal kitaplar, dua metinleri, ibadet yerleri (cami, sinagog ve kilise gibi) ve ayinler, dini diasporanın en önemli belirleyici özellikleridir.

3) Politik diasporalar: Anavatanlarının yabancı bir kuvvet tarafından işgal edildiği ve diaspora üyelerinin tek gayesinin bağımsız bir ulus-devlet inşa etmek olduğu zamanlar ortaya çıkmaktadır. Bunun en bariz örneği Filistin diasporasıdır.

4) Irksal ve kültürel diasporalar: Diaspora üyeleri aynı ırk ya da aynı kültüre sahip oldukları ve buna inandıkları için örgütlenmektedir. Ortaklaşarak inşa edilen kimliklerin tanımlanmasında yine ırk ve kültür belirleyicidir. Örneğin, siyahlar diasporası. Afro-Amerikalıların bir diaspora olarak tanımlanmasında aynı renk ya da aynı ırka sahip olmaları; köle ticareti ve büyük çiftliklerin köle işgücü gibi ortak deneyimler büyük rol oynamıştır.

\subsection{Diasporanın Anavatanlarının Siyasi Durumu Açısından Sınıflandırılması}

Sheffer, diaspora olarak adlandırılan toplulukların anavatanlarının siyasi durumu açısından kavramı, devletli diasporalar ve devletsiz diasporalar olarak iki kategoride ele almaktadır. Devletsiz diaspora, orijin vatanlarının tam olarak bilinmediği ya da orijin vatanlarının başka uluslar tarafından işgal edildiği ve yönetildiği diasporayı tanımlamak için kullanılmaktadır (2003: 23). Devletli diaspora ise, tam aksine mevcut bir devletin ve somut bir anavatanının var olduğu bir durumdur. Örnek olarak, İngiltere'deki Türk diasporasl.

\subsection{Diasporanın Tarihsel Açıdan Sınıflandırılması}

Kavramı tarihsel bağlamda inceleyen Michele Reis (2004: 41) diasporayı kronolojik olarak üç ayrı dönemde ele almaktadır:

1) Klasik diasporalar: Antik çağlardan 1500'li yıllara kadar olan süreçte oluşan diasporalar. Örneğin, Yunan diasporası, Yahudi diasporası ve Ermeni diasporası.

2) Modern diasporalar: 1500'lı yıllardan 1945'e kadar olan süreçte ortaya çıkan diasporalardır. Örneğin, Kuzey Amerika'ya ve Avrupa'ya doğru gerçekleşen büyük göç hareketleriyle (savaş, kölelik, sürgün, iş aramak gibi) oluşan diasporalar.

3) Çağdaş diasporalar: 1945'li yıllardan şimdiye kadar olan süreçte şekillenen diasporalar. Örneğin, ABD'deki Hispanicler. 
Reis'in sınıflandırmasına göre, geçmişteki büyük felaketler, savaşlar, hastalıklar, sürgünler ve diğer tarihi olayların diasporanın oluşumundaki etkilerini anlayabilmek açısından büyük bir öneme sahiptir.

\subsection{Diaspora Üyelerinin Konumları Açısından Sınıflandırılması}

Her diaspora üyesine, bulunduğu ev sahibi ülkede ister istemez belli bir konum ve statü atıf edilmektedir. Atıf edilen bu konum da diaspora üyelerinin ev sahibi ülkede bulunma neden ve amaçları tarafından belirlenmektedir. Bu bağlamda Cohen (1997: 179), diasporaları daha farklı bir bakış açısıyla sınıflandırmaktadır. Bu sınıflandırmada daha çok diasporanın ev sahibi ülkede bulunma neden ve amaçlarının yanında bulunduğu coğrafyada diaspora üyeleriyle özdeşleştirilen konuma vurgu yapılmaktadır.

1) Mazlum diasporası: Afrika'lılar, Yahudiler ve Ermeniler.

2) İşçi diasporası: Hintliler, Türkler.

3) İşgal diasporası: İngilizler, Fransızlar, İspanyollar.

4) Ticaret diasporası: Lübnanlılar, Çinliler.

5) Kültür diasporası: Karayipliler.

\section{Uygur Diasporasının Yapısal Özellikleri}

Yakın tarihte Doğu Türkistan'dan diğer ülkelere yapılan göç hareketleri 20. yy'ın ikinci çeyreğinde başlamıştır. 1933 yılında kurulan Doğu Türkistan İslam Cumhuriyeti'nin Çin yönetimi tarafından yıkılmıştır. İkinci kez 1944 yılında kurulan Doğu Türkistan Cumhuriyeti'nin 1944 yılında yine Çin yönetimi tarafından 1949 yılında işgal edilmesinden sonra faklı tarihlerde farklı göç hareketleri gerçekleştirilmiştir. Bağımsız bir ulus devletin kaybedilmesiyle birlikte komünist işgalcilerin yaptığı hak ve hukuk ihlalleri geniş çaplı göç hareketlerine neden olmuştur.

1933-1964 yılları arasında Doğu Türkistan'dan farklı ülkelere göç hareketleri yapılmıştır. 1935-1937 yıllarında Mahmut Muhiti ile bir göç gerçekleştirilmiştir. Aynı dönemde Altay'dan Kazaklar kafileler halinde göç etmiștir. 1949 yılında ise Alibek Hakim, İsa Yusuf Alp Tekin, Hüseyin Teyci, Mehmet Emin Buğra ve Delilhan Canaltay gibi önemli kişiler Hidinsitan'a ve Pakistana göç etmiştir. 11 Eylü, 17 Eylül ve 20 Eylül 1949 tarihlerinde Canımhan Hacı, Mehmet Emin Buğra ve İsa Yusuf Alp Tekin liderliğindeki kafileler Doğu Türkistan'dan ayrılmıştır. Bu göçün amacı sadece iyi yaşama imkanlarına sahip olmak ve hayatta kalmak değil belki anavatanlarında devam ettirme imkânı bulamayan bağımsızlık mücadelesini yurt dışında sürdürmek olmuştur. Vatan için vatanından ayrılmak zorunda kalan kafileler Türkiye bașta olmak üzere Kazakistan, Kırgızistan, Özbekistan, Pakistan, Afganistan'a yerleşmiştir. Türkiye'ye ulaşan kafileler ise 10 Mart 1952 tarihinde Türkiye Cumhuriyeti Bakanlar Kurulu Kararıyla "İskanlı Göçmen" olarak kabul edilmiştir (Kul, 2017: 75-76). 1952 sonrası Türkiye'ye göç eden Doğu Türkistanlılar: Niğde vilâyeti Aksaray kazası Sultanhan nahiye merkezine, Manisa vilâyeti Salihli kazası merkezine, Kayseri vilâyetinin Develi kazası Sindelhöyük ve Karacaviran köyleri ile Yahyalı kazasına bağlı Kopçı ve Hocahacıllı köylerine, Doğu Türkistanlı göçmenlerin kendi memleketlerinin ismini verdikleri Niğde vilâyetinin Ulukışla kazasına bağlı Altay köyüne, Konya Ereğlisi'ne, Konya vilâyeti merkez köylerinden İsmil'e, Adapazarı'nın merkezine yerleşmişlerdir (Kul ve Tuncer, 2015: 222). 1960 yılının Ağustos ayında Pekin'de imazalanan “Afganistan ile Çin Arasında Sınır Serbestliği" anlaşmasından haberdar olan Mehmet Kasım Cantürk 130 kişilik bir kafile olurştuırmuş ve 1961 yılında Afganistan'a göç etmiştir (Tuncer, 2014: 272). 1961 yılında Afgansitan’a göç eden Doğu Türkistanlıların Türkiye’ye iskanlı göçmen olarak getirilmesi için bazı arayışlarda bulunulmuş ve Türkiye Hükümetiin olumlu yanıt 
vermsiyle Afgansitan'da bulunan Doğu Türkistanlıların bir kısmı Türkiye'ye iskanlı göçmen olarak yerleştirilmiştir (Tuncer, 2018: 217).

1967 yılından sonraki dönemlerde büyük çapta göç hareketi geçekleşememiştir. Binlerce Uygur'un ölümü, yaralanması ve kaybolmasıyla sonuçlanan 5 Temmuz 2009 katliamı sonrasında bile çok az sayıda Doğu Türkistanlı yurt dışına çıkabilmiştir. Bunun en önemli nedeni ise, Çin yönetimin Uygurlara getirdiği seyahat özgürlüğü kısıtlamasından dolayı Uygurların pasaport alamaması ve gümrük kapıları ve sınır bölgelerinin bir sineğin bile yurt dışına çıkışına izin verilmeyecek kadar sıkı denetlenmesidir. Bu yüzden gerek yasal yollarla gerekse kaçak yollarla yurt dışına çıkış imkânı bulunamamaktadır.

Günümüzde Türkiye başta olmak üzere Kazakistan, Kırgızistan, Özbekistan, Pakistan ve Afganistan'ın yanı sıra ABD, Hindistan, Kanada, AB, Rusya, Japonya ve Suudi Arabistan'da yaşam mücadelesi veren Doğu Türkistanlılar bulunmaktadır.

Anavatan için anavatanlarını terk edip farklı ülkelerde yaşamakta olan Uygur topluğunun özellikleri, Gabriel Sheffer'in yurt dışında (anayurtlarından başka bir coğrafyada) yaşayan toplulukların diaspora olarak adlandırılabilmesi için oluşturduğu niteliklerle ele alındığında, yurt dışında yaşayan Uygur topluluğu daha iyi anlaşılacaktır:

1) Yurt dişında yaşayan az sayıdaki Uygurlar hariç çoğu Uygur kendi kimliğini, dinini, kültürünü ve bir birey olarak temel hak ve hukuklarını koruyabilmek için göç etmek zorunda kalmıştır. Hatta hayati tehlikesi bulunduğundan kendi canını koruyabilmek için göç edenler de mevcuttur.

2) Doğu Türkistan'dan göç edenler sadece Uygurlardan ibaret değildir. Uygurların yanı sıra Kazak, Kırgız ve Özbek gibi topluluklar da Doğu Türkistan'dan (ana vatanlarından) göç etmek zorunda kalmıştır. Gerek Uygurlar gerekse diğer topluluklar, aralarında kısmen farklılıkların olmasına rağmen aynı etnik ve dini kökten geldiklerini kabul eder ve yurt dışında aynı amaç uğruna örgütlenirler. Örneğin, Kazakistan ve Türkiye'deki bazı STK'ların siyasi faaliyetleri.

3) Anayurtlarının dışında bir ya da birden fazla ülke ve coğrafyalarda azınlık topluluk olarak yaşamını sürdürürler. Örneğin Türkiye bașta olmak üzere Orta Asya, Güney Doğu Asya, ABD, Avrupa ve diğer ülkelerde yaşayan Uygur topluluğu bulunmaktadır.

4) Doğu Türkistan'dan göç edenler, bir yandan anayurtlarıyla bir yandan da diğer ülkelerde yaşayan soydaşlarıyla olan ilişkilerini sürdürmektedirler.

5) Topluluğun üyeleri birbirleriyle hem gerçek dünyada hem de sanal dünyada sürekli yoğun bir iletişim ve dayanışma içindedirler. Siyasi, iktisadi ve diğer toplumsal amaçları doğrultusunda örgütlenebilmekteler.

6) Aktif olarak rol aldıkları sosyal, kültürel, siyasi ve ekonomik çabalarının yanı sıra, diaspora mensupları, anayurtları, ev sahibi ülkeler ve başka ülkeler arasında kurulan ilişkileri etkileyerek devlet-ötesi iletişim ağlarını şekillendirir. $\mathrm{Bu}$ anlamda, son zamanlarda birçok ikinci dünya ve üçüncü dünya ülkelerinin kendi sınırları içinde ikamet eden Uygur topluluklarını Çin'e karşı bir koz ya da pazarlık konusu olarak kullanmaları ve hatta Çin'in isteği üzerine Uygurları Çin istihbarat birimlerine teslim etmeleri bunun bariz bir örneğidir.

Yukarıdakilerden anlaşılacağı üzere, Sheffer'in anavatanlarının dışındaki coğrafyalarda yaşayan herhangi bir topluluğu diaspora olarak nitelendirmek için geliştirdiği kriter ve özellikler açısından bakıldığında, yurt dışında yaşayan Uygur topluluğu sözü edilen özelliklerin neredeyse tümünü taşımakta ve gerçek bir diaspora olarak nitelendirilmektedir. 
Uygur diasporasını daha iyi kavramak adına, bu diasporanın örgütlenme nedenlerine, anavatanlarının siyasi durumuna, ortaya çıktığı tarihsel dönem ve üyelerinin bulunduğu ülkelerdeki konumlarına bakmakta fayda vardır.

Uygur Diasporasının Örgütlenme Nedenlerine Bakıldığında:

Michel Bruneau'a göre, anavatanlarından ayrılarak yurt dışında hayatlarını devam ettiren toplulukların örgütlenmelerinin ardında genel olarak din, ticaret, siyaset, aynı ırk ve aynı kültür gibi öğeler yatmaktadır. Yani bunlardan herhangi biri ya da birkaçının kombinasyonu diasporanın oluşmasına neden olan temel öğelerdir (2010: 77). Bu açıdan bakıldığında, Uygur diasporasını politik diaspora aynı zamanda ırksal ve kültürel diaspora olarak da sınıflandırmak mümkündür. Yani anavatanları yabancı bir kuvvet tarafından işgal edilmiştir ve diaspora üyelerinin tek gayesi bağımsız bir ulus-devlet inşa etmektir. Örgütlenme nedenleri bu amaç uğrunadır. Ayrıca, diaspora üyeleri aynı ırk ya da aynı kültüre sahip oldukları, aynı kimliği taşıdıkları ve buna inandıkları için de bir arada bulunurlar. Zira yurt dışında yaşayan bir kısım Uygurlar, bağımsız bir devlet kurma isteği (yani siyasi bir amacı) olmamasına rağmen, aynı kültür ve aynı kökten geldikleri için Uygur topluluğuna dahi olmakta ve bu nedenle örgütlenmektedir.

Uygur Diasporasının Anavatanlarının Siyasi Durumuna Bakıldığında:

Gabriel Sheffer, diaspora olarak adlandırılan toplulukların anavatanlarının siyasi durumu açısından diasporaları, devletli diasporalar ve devletsiz diasporalar olarak iki kategoride ele almaktadır (2003: 23). Bu bakımdan, Uygur diasporasını devletsiz diaspora olarak nitelendirebiliriz. Ana vatanları işgalci güçler tarafından işgal edilmiş ve yönetilmektedir. Diaspora üyeleri, orijin vatanları olarak bildikleri coğrafyada somut anavatana sahipken mevcut bir devletten mahrumdurlar. Somut ve bağımsız bir ulus devletini yeniden kuracaklarını idealize etmekte ve bu amaçla örgütlenmektedirler.

Uygur Diasporasının Ortaya Çıktığı Tarihsel Döneme Bakıldı̆̆ında:

Michele Reis diasporayı kronolojik olarak üç ayrı döneme ayırmaktadır. Klasik diasporalar, modern diasporalar ve çağdaş diasporalar (2004: 41). Reis'in belirttiği tarihler baz alındığında, Uygur diasporası çağdaş diaspora olarak sınıflandırılır. Gerçi daha eski dönemlerde de felaketler, savaşlar, hastalıklar, süngünler ve diğer tarihi olaylardan ötürü anayurtlarından ayrılanlar olsa da zaman içerisinde bulunduğu coğrafyalardaki topluluklarla karışmış, bütünleşmiş ve erimiştir. Anayurtlarına duyulan özlem ve dönme hayali taşımadıkları için diaspora olarak nitelendirmek pek mümkün değildir. Dolayısıyla gerçek anlamda anavatanına dönme isteği ve kendi kimliğini koruma çabasıyla yaşayan Uygur topluluğu 1945 'ten sonra oluşmaya başlamıştır. Bu yüzden Uygur diasporasını tarihsel bağlamda çağdaş diaspora olarak değerlendirmek isabetli olacaktır.

Diaspora Üyelerinin Bulunduğu Ülkelerdeki Konumlarına Bakıldığında:

Her diaspora mensubuna, ikamet ettiği ülkede ya da coğrafyada ister istemez belli bir konum ve statü biçilmektedir. Biçilen bu konum, diaspora mensuplarının o ülkede ya da coğrafyada ikamet etme sebepleri ve amaçları doğrultusunda belirlenmektedir. Diasporayı bu bağlamda ele alan Cohen, diasporaları mazlum, işçi, işgal, ticaret ve kültür diasporası olarak beş ayrı kategoriye ayırmaktadır (1997: 179). Haksızlığa uğrayarak ve hakkı gasp edilerek anavatanlarından ayrılmak zorunda kalan ve bulunduğu ülkelerde ev sahibi topluluk nezdinde müstazaf bir konum atfedilen Filistinli diasporası gibi Uygur diasporası da bir mazlum diasporasıdır. 


\section{Uygur Diasporasının Yapılanma Tarzı}

Dufoix (2011: 66), yurt dışında ortak deneyimin yapılanma tarzıyla ilgili olarak dört farklı yapılanma tipi önermektedir. Bu yapılanma tiplerini aşağıdaki Şekil-1'de daha açıklayıcı biçimde görmek mümkündür.

Şekil-1'degösterildiği gibi, yurt dışında yaşayan toplulukların yapılanma tarzları merkezçevre, dışa kapalı, atopik ve çatışmacı olmak üzere dört farklı biçimde incelenmektedir. Dufoix'e göre (2011: 66):

1) Merkez-çevre yapılanması: Göç edilen ülkede göç sonucu bir topluluğun var oluşu ve bir arada bulunmaları, bu göçmenlerin anavatanlarıyla doğrudan ilintilidir. Resmî kurumların-örneğin büyükelçilik, konsolosluk, kütür merkezleri vb. kuruluşlar- yanı sıra bu göçmenlerin temsil edildikleri dernek ve vakıf gibi sivil kurumlar da göçmenler ile anavatanları arasında önemli rol oynar. Hatta devlet, yurt dışında yaşayan tüm vatandaşlarının haklarının korunması ve temsilinin sağlanması için bu dernek ve vakıfları bir araya getirerek vatandaşlarını örgütleyebilmektedir. Bu yapılanma tarzında, göçmenler için devlet bir bakıma anavatan ile eşdeğerdir. İster resmi ya da gayri resmi kuruluşlar aracılığıyla olsun ister aracısız olsun yurt dışında yaşayan vatandaşlar anavatanlarıyla karşılıklı ilişsi içerisinde ve doğrudan bağlantılıdır. Bu karşılıklı ilişkide temsili kurumlar büyük role sahiptir.

2) Dışa kapalı yapılanma: Göç edilen ülkede genellikle bir şehrin belli mahallelerinde yaşayan topluluğun örgütlenmesidir. Mahalle bazında örgütlenerek toplu halde yaşamaya çalışan bu göçmenler, çoğu zaman şehir dokusunun içinde yer almakla birlikte aynı kökten aynı ırktan geldikleri için değil belki aynı yaşam şartlarına sahip oldukları için bir arada bulunur ve örgütlenirler. Yerel düzeyde ve küçük çapta faaliyet gösterir ve dayanışma içindedirler. Merkez-çevre yapılanmasının aksine, bu yapılanma tarzında göçmenlerin bir arada bulunma nedeni resmi bir ulusal bağa değil, benzer kimlikler ve yaşam koşullarına dayanmaktadır. Ayrıca, göçmenlerin devlet ile bağları zayıftır ve hatta hiçbir ilişkisi bulunmamaktadır.

3) Atopik yapılanma: Bu devlet ötesi bir yapılanma tarzıdır. Ama fiziksel anlamda bir bağımsız devlet kurma ve toprak edinme gibi bir dertleri ve gayeleri yoktur. Göç edilen ülkelerin vatandaşı olmadan, bulunduğu ülkenin kimlik ve kültürüne entegre olmadan devletler arasında yaşarlar. Ortak bir köken, etnik ya da dini kimlik etrafında oluşan hayatta kalma çabasıdır. Birçok ülkede yaşamını sürdürürler. Birden çok mekânı kapsayan ve ağlarıyla tarif edilen uzam dişında toprağı olmayan bir coğrafya ve bu coğrafyanın vatandaşlarıdır. Atopik yapılanmada, vatandaşlar devlete tamamen kayıtsız ve ilgisizdir. Örneğin Romanlar.

4) Çatışmacı yapılanma tarzı: Diasporanın bu tip yapılanması atopik yapılanma gibi devlet ötesi bir yapılanmadır. Fakat anayurtlarında söz sahibi olan rejiminin mevcudiyetini ve meşruluğunu reddeden, kendi topraklarının yabancı güçler ya da uluslar tarafından işgal edilen veya işgal edildiğini düşünen insanların oluşturduğu hem ulusal hem de devlet ötesi bir yapılanmayı ifade etmektedir.

Doğal olarak böyle bir çatışmacı özelliğe sahip olan diasporanın amacı, kendi vatanını, ulusunu ve topraklarını işgalcilerden kurtarmak olacaktır. Bu amaca ulaşabilmek için bağımsızlık mücadelelerinin meşruluğunu büyük güçler tarafından onaylanmasına ve tanınmasına çabalar. Bazı durumlarda bu mücadele diplomatik yollarla yürütülürken, bazı durumlarda gerilla savaşı şeklinde de gerçekleştirilebilir. 
Şekil-1. Yurt Dışında Ortak Deneyimin Yapılanma Tipleri
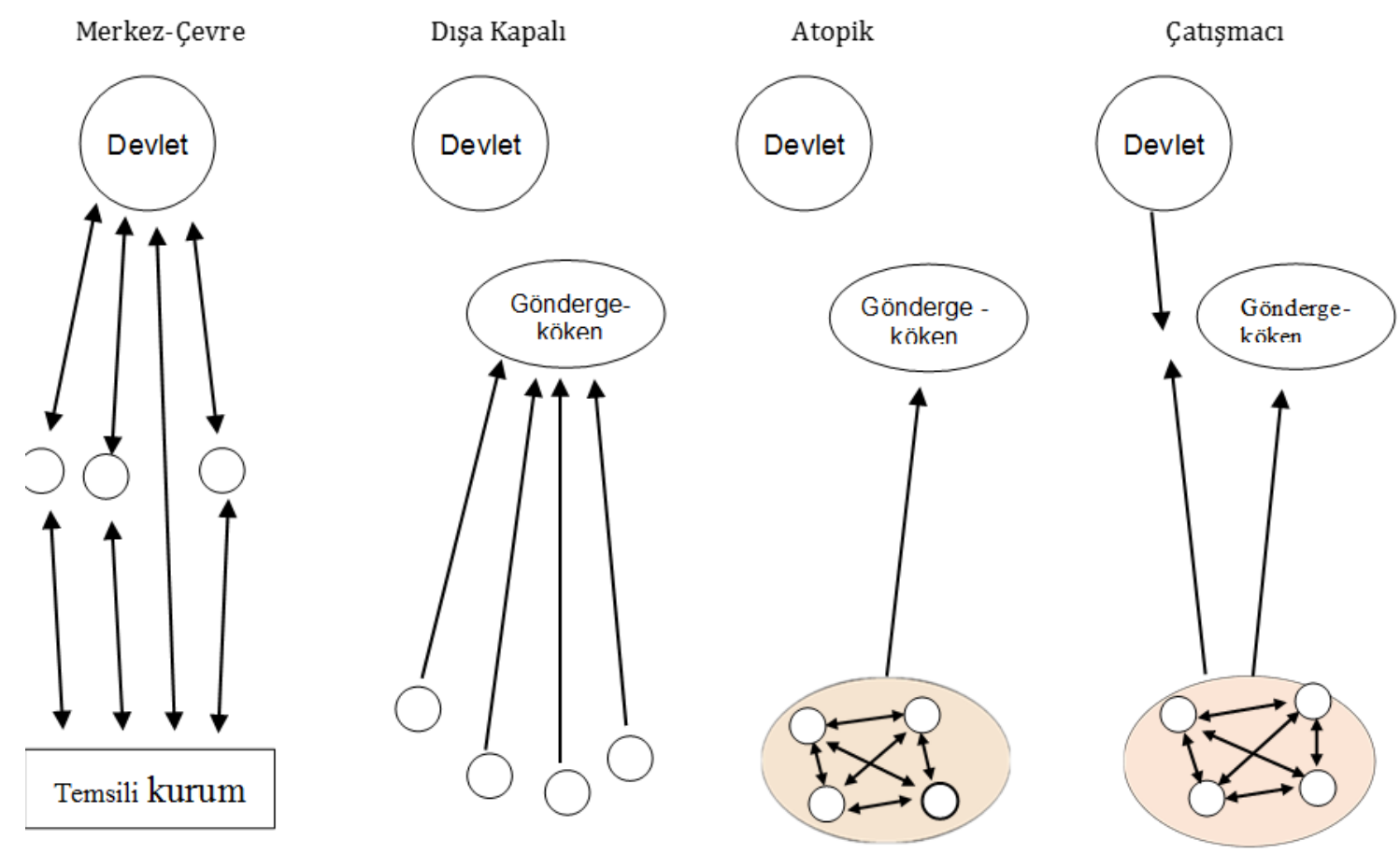

Başka bir ülkede yerel olarak örgütlenmiș topluluk

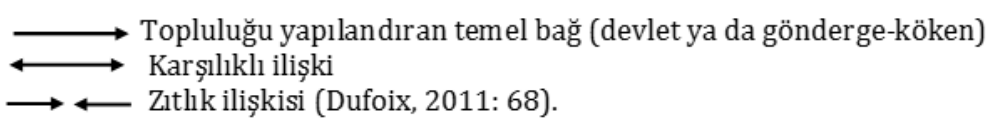

Diasporanın yukarıda dile getirilen dört faklı yapılanma biçimlerine bakıldığında, Uygur diasporası çatışmacı yapılanma modelinde yer almaktadır. Yani anayurt olarak bildikleri 1 milyon 800 bin kilo metrekarelik Doğu Türkistan coğrafyası, Çinliler tarafından işgal edilmiş ve diasporayı oluşturan üyeler de bu işgali ve rejimin mevcudiyetini reddetmektedir. Hem birey olarak hem de diaspora olarak sürgün hayatının amacı anayurtlarını işgalci güçlerden kurtarmak olmuştur. Bu amaca ulaşmak için mücadele ederken; silah, savaș desteği ve bașka imkanları bulunmadığından diplomatik yollara başvurarak bağımsızlık davalarının haklılığının ve meşruiyetinin ABD, Japonya ve bazı batılı ülkeler tarafından tanınmasına çaba sarf etmektedir. Anayurtlarındaki mevcut rejimle ya da resmi devletle zıt bir ilişki içerisinde olan Uygur diasporası, gönderge köken ile tek yönlü bir ilişki ve iletişim içerisindedir. Gönderge kökene özlem duyar, kavuşmak ister, yeniden inşa etmek ve dönmek ister. Fakat gönderge kökenle olan ilişki bağlamında Uygur diasporasının en büyük dezavantajı ise teknolojiyle donatılmış 21. yüzyılda yaşıyor olmasına rağmen, gönderge köken ile hiçbir iletişiminin olmaması ve dolayısıyla gönderge kökeninin uzak coğrafyalarda böyle bir oluşumun, kendilerine yönelik özlemin ve bağımsızlık mücadelesinin varlığından haberlerinin bile olmamasıdır.

Uygur diasporasının diğer birçok diasporaya pek benzemeyen bir yönü de iç ve diş diaspora ayrımıdır. 1964 yılından sonra Ermeni diasporasının Sovyetler Birliği sınırları içerisinde yer alan iç diaspora ve bu sınırların dışında yer alan diş diaspora olarak bölünmesi gibi, Uygur diasporası da Çin sınırları içerisinde yer alan iç diaspora ve bu 
sınırların dışında yer alan dış diasporadan oluşmaktadır. Fakat sadece kendi değer, kültür ve kimliklerinin korunması ve devamı için çabalamakla yetinen, genellikle üniversite öğrencileri ve az bir kısım iş adamlarından oluşan bu iç diasporanın dış diasporadan en belirgin farkı ise, herhangi bir siyasi örgütlenme ve bağımsızlık davası gütmemesidir.

\section{Sonuç}

"Diaspora" kavramının temeline bakıldığında, ardında yatan şeyin zorlama ve çaresizlik olduğunu söylemek mümkündür. Her diasporik varoluş, hak edilmiş yaşam biçimi değil belki hak edilmeyen zorlamaların sonucudur. Diasporalar, kimse böyle bir yaşam istediği için ortaya çıkmış değildir (Dufoix, 2011: 20). Zorluklar, acılar ve türlü sıkıntılarla yüklü bir hayatta kalma biçimidir. İstenilen ve arzu edilen bir varoluş biçimi değildir. Diaspora üyelerini bir arada tutan ve birbirlerini bağlayan şey ise bu tür var olmaya neden olan ortak geçmiş, ortak hafıza, acı, zorlama ve çaresizlikler ve bunlara yol açan nihai sebeplerdir.

Örgütlenme nedenleri politik, ırksal ve kültürel temellere dayanan Uygur diasporası ortak geçmiş, ortak hafıza, ortak acı, ortak zorlama ve çaresizliklerden ötürü aynı kimliği taşımakta ve buna inandıkları için de bir arada bulunmaktadır. Ana vatanları işgalci güçler tarafından işgal edilmiş ve yönetilmekte olan bu topluluk, devletsiz diaspora olarak nitelendirilmektedir. Diaspora üyeleri, orijin vatanları olarak bildikleri coğrafyada somut anavatana sahipken mevcut bir devletten mahrumdurlar. Somut ve bağımsız bir ulus devletini yeniden kuracaklarını idealize etmekte ve genel anlamda bu amaçla örgütlenmektedirler. Birinci dünya savaşından sonra oluşmaya başlayan Uygur diasporası, tarihsel bağlamda çağdaş diaspora olarak tanımlamak mümkündür. İkamet ettiği ülkelerde ya da coğrafyalarda müstazaf bir konum atfedilerek Filistinli ve Suriyeli diasporası gibi mazlum diasporası sıfatını taşımaktadır. Çatışmacı yapılanma biçiminde örgütlenen bu diaspora; anayurtlarını, ulusunu ve topraklarını işgalci güçlerden kurtarmak için diplomatik yollarla mücadele etmektedir. Bağımsızlık davalarının haklılığını korumak ve bunun güçlü devletler tarafından tanınması ve onaylanması arayışı içindedir.

$\mathrm{Bu}$ çalışma Uygur diasporasının temel özellikleri, yapılanma tarzı ve kısa tarihçesi üzerinde durmuştur. Uygur diasporsına giriş nitelğinindedir. Elbette hem var kalma çabası hem de bağımsızlık mücadelesi her geçen gün zorlaşmakta olan Uygur diasporası daha yoğun ve derin araştırmalar gerektiren bir konudur. Uygur diasporasının, karşılaştığı sorunlar (ekonomik, siyasi ve kültürel açıdan); bulunduğu coğrafyalardaki siyasal sistemle ilişkisi; bulunduğu coğrafyadaki siyasal sistemin Çin devletiyle ilişkisi ve ana vatanlarının mevuct durumu bağlamında araştırılması konunun daha iyi anlaşılmasın katkıda bulunacaktır.

\section{Kaynakça}

ALFRED, Mary. (2015). Transnational Migration, Social Inclusion, And Adult Education: New Directions For Adult And Continuing Education. San Francisco: Jossey Bass.

BAUMANN, Martin. (2000). "Diaspora: Genealogiess Of Semantics And Transcultural Comparison”. Numen, Vol. 47, pp. 313-337.

BRUNEAU, Michel. (2010). Diaspora, Transnational Spaces And Communities. Diaspora and Trans Nationalism: Conseptts, Theories and Methods. (Ed.: R. Bauböck ve T. Faist). Amsterdam: Amsterdam University Press.

COHEN, Robin. (1997). Global Diaspora: An Introduction. London: Ucl Press. 
DUFOIX, Stephane. (2011). Diasporalar. (Çev.: I. Ergüden), Ankara: Uluslararası Hirant Dink Vakfı Yayınları.

KUL, Ömer ve TUNCER, Tekin. (2015). "XX. Asırda Doğu Türkistan'da Göçler”. Türk Dünyasında Sürgün ve Göç, s. 193-232.

KUL, Ömer. (2017). 100 Soruda Doğu Türkistan. İstanbul: Rumuz Yayınları.

LAYCOCK, Joanne. (2012). "Armenian Homelands And Homecomings: 1945-9". Cultual And Social History, Vol. 9, pp. 103-123.

REİS, Michele. (2004). "Theorizing Diaspora: Perspectives on Classical and Contemporary Diaspora". International Migration, Vol. 42, pp. 41-56.

SAFRAN, William. (1991). "Diasporas in Modern Societies: Myths of Homeland and Return". Diaspora, Vol.1, pp. 83-99.

SHEFFER, Gabriel. (2003). Diaspora Politics: At Home Abroad. Cambridge: Cambridge University Press.

TUNCER, Tekin. (2014). “Doğu Türkistan'dan Türkiye’ye Yapılan 1961 Göçü ve Mehmet Kasım Cantürk". I. Uluslararası Türk Kültürü Araştırmaları Sempozyomu, s. 270-278.

TUNCER, Tekin. (2018). “Türkiye'de Yaşayan Doğu Türkistanlıların Kurduğu Sivil Toplum Örgütleri ve Bunların Faaliyetleri: Doğu Türkistan Göçmenler Cemiyeti Örneği”. History Studies, Vol. 10, pp. 205-221.

YALDIZ, Fırat. (2013). "Diaspora Kavramı: Tarihçe, Gelişme ve Tartışmalar”. Hacettepe Üniversitesi Türkiyat Araştırmaları Dergisi, S.18, s. 289-318. 